\title{
Human rights, colonialism and post-colonial conflict resolution: historical justice litigation
}

\author{
by Tom Frost and Sascha-Dominik Bachmann
}

$\mathrm{H}$ uman rights campaigners, activists and litigators have been seeking ways and means to hold accountable those responsible for gross human rights abuses and violations. These measures have included seeking the criminal prosecution of the individual human rights perpetrator, as well as seeking civil damages against individual actors.

The rationale and means of human rights protection can be found in the international legal system. International law plays two critical roles in relation to the protection of human rights. First, it establishes acceptable norms of conduct, such as the prohibition of torture. Second, it provides, where possible, enforcement mechanisms that aid and support the domestic enforcement of these norms (Tyler Giannini and Susan Farbstein, "Corporate Accountability in Conflict Zones: How Kiobel Undermines the Nuremberg Legacy and Modern Human Rights," (2010) 52 Harvard International Law Journal 119, 124).

The protection of human right reflects on the hybrid nature of its origin, rationale and raison d'etre, which holistic nature can be best summarised in the words of the Inter-American Court of Human Rights (IACtHR), which said that whereas:

"the international protection of human rights should not be confused with criminal justice. [...] The objective of international human rights law is not to punish those individuals who are guilty of violations, but rather to protect the victims and to provide for the reparation of damages resulting from the acts of the States responsible" (see the Velasquez Rodriguez decision of 1988 (Ser C No 4 reported in (1988) 9 Human Rights Law Journal 212, para 134)).

However, at present there seems to be a lack of an effective international enforcement mechanism for human rights abuses. The existing UN Charter and treaty-based human rights systems suffer in general from an absence of strong and effective inter- and intra-state accountability mechanisms. Consequently, the existing human rights protection regimes are "weak" in terms of available sanctions and remedies against a violating state and even weaker in respect to the eventual enforcement of such sanctions (Cf Bachmann, Civil Responsibility for Gross Human Rights Violations - the need for a global instrument, monograph published by Pretoria University Law Press (PULP)).

Measures to ensure compliance and redress for human rights violations have often focused solely upon the domestic sphere. The reasons for this are due to the perceived relationship between national and international law. The prevailing view of Anglo-American jurisprudence views national law as having primacy over international law: international laws apply when the nation state passes treaties or statutes which make clear their applicability. (Hans Kelsen, "Sovereignty and International Law", (1960) 48 The Georgetown Law Journal 627, 630).

There are generally two routes for the restitution of human rights violations: the domestic, territorial, and the transnational, extraterritorial litigation approach. The domestic route allows for citizens who have suffered wrongs from their government or other private actors to bring cases in the courts of their own state. The transnational route allows for victims of human rights abuses to bring actions in other states. Both approaches have their weaknesses.

The national approach relies upon the nation state itself to provide justice in its court system and court procedure. The transnational approach could lead to the nation state being inundated with transnational claims and seeking to foreclose any future claims. After a state allows for the redress of violations of international law in its courts, that state can become a focus for the global human rights movement. Such a move has occurred most famously in the United States. Developed as litigation against the individual perpetrator and the corporate aider and abettor of human rights violations, it is known by the shorthand of human 
rights litigation. Developed over the last 30 years, this form of extraterritorial litigation has altered existing perceptions that only states could commit such human rights atrocities and that accountability could only be sought within the parameters of existing interstate relations.

"Human rights litigation contributes to an important longterm objective: working toward a world in which those who commit gross violations of human rights are brought to justice swiftly, in whatever country they try to hide" (Beth Stephens, International Human Rights Litigation in US Courts (2008))

In 1980, the Court of Appeals for the Second Circuit in the case of Filártiga (Filártiga v Peña-Irala, 630 F.2d 876 (2d Cir. 1980), 28 U.S.C. $\$ 1350$ (1994) ruled that individual aliens could bring claims for violations of the law of nations under the Alien Tort Statute, or ATS. This has led to cases being brought in US Federal courts claiming damages for genocide, war crimes, summary execution, disappearance, and arbitrary detention.

Yet, the ATS litigation which has reached the Supreme Court points to a sceptical outlook for extraterritorial claims. In Sosa v Alvarez-Machain (Sosa v Alvarez-Machain, 542 U.S. 692 (2004) (SCOTUS), the court considered a claim brought under the ATS by a Mexican citizen against another Mexican citizen for a kidnapping that occurred in Mexico (Sosa, 714). The court in their decision limited the applicability of the ATS. The court accepted that federal courts did have jurisdiction over torts in violation of the "law of nations", but strictly limited the category of offences which were defined by their universal acceptance, their obligatory nature and high degree of specificity (Sosa, 732).

This limitation upon ATS litigation could be in the process of being extended. In Kiobel, the question posed before the court was whether corporate civil tort liability under the ATS justiciable, or whether corporations were immune for tort liability under the ATS Kiobel $v$ Royal Dutch Petroleum, No. 10-1491 (argued February 28, 2012) (SCOTUS)). During oral argument, Justice Alito expressed concern at the very extraterritorial nature of the ATS:

'The first sentence in your brief in the statement of the case is really striking: "This case was filed ... by twelve Nigerian plaintiffs who alleged ... that respondents aided and abetted the human rights violations committed against them by the Abacha dictatorship ... in Nigeria between 1992 and 1995." What business does a case like that have in the courts of the United States?'(Kiobel, oral transcript, p 11, 16-24 http://Www.supremecourt.gov/oral_arguments/argument_transc ripts/10-1491.pdf)

Justice Alito thus clarifies the court's concern in Sosa why should offences committed abroad be justiciable in American courts? Do prudential considerations (ensuring certainty in the law) disqualify such extraterritorial actions?

These concerns point toward a larger issue underlying the court's decision-making, namely the rule of law. There is an ambiguity surrounding the rule of law at the heart of historical justice litigation. Historical justice litigation is marked by an adherence to the rule of law, a desire to see the rule of law upheld and justice done. However, such litigation supports a substantive, rather than a formal, conception of the rule of law. The dichotomy between formal and substantive conceptions of the rule of law is crucially important in determining the nature of the specific legal precepts which can be derived from it (Craig, "Formal and Substantive Conceptions of the Rule of Law: An Analytical Framework” 1997 Public Law 467).

The term appears so self-evident that it seems to need no definition. However, this lack of definition brings to the fore the importance of whether the rule of law is given substantive or formal meaning. Formal conceptions of the rule of law address the manner in which the law was promulgated, the clarity of the ensuing norm and whether the norm was promulgated prospectively or retrospectively (Craig 467). Such conceptions do not seek to pass judgment upon the actual content of the law itself. This can be contrasted to substantive conceptions of the rule of law, which seek to develop certain substantive rights which are claimed to derive from, or be based upon, the rule of law. The rule of law founds these rights, which can be used to distinguish between "good" laws which comply with such rights, and "bad" laws which do not (Craig 467-68).

The content of this foundational legal concept will differ greatly depending upon whether a procedural or substantive viewpoint is adopted. This is the case as there are certain principles which can be posited as forming part of the rule of law. The most important can be said to be the principle that all persons are to be treated equally under the law. The implications of this principle, equal treatment under the law, differ depending on whether formal or substantive definitions of equality are adopted. Formal equality is as old a principle as Western political philosophy: if two persons have equal status in at least one normatively relevant respect, they must be treated equally with regard to this respect. As Aristotle stated, we are to "treat like cases alike" (Aristotle, Nicomachean Ethics (1984), Book 53 1131a10-b15).

It was a concern for the key formal principles of the rule of law which led the Supreme Court to order Kiobel to be expanded and reargued. The new question the court will answer is:

\footnotetext{
"Whether and under what circumstances the Alien Tort Statute, 28 U.S.C. \$ 1350, allows courts to recognize a cause of action for violations of the law of nations occurring within the territory of a sovereign other than the United States”, (10-1491, Kiobel, Esther, et al. v Royal Dutch Petroleum, et al., Order in Pending Case, March 5, 2012, http://sblog.s3.amazonaws.com/wp-content/uploads/ 2012/03/10-1491-order-rearg-3-5-12.pdf)
}

The overall impact of the ruling in Kiobel for the future scope of human rights actions in the context of the 
extraterritorial commission of breaches of international law in direct and indirect liability will have to be seen.

Irrespective from Kiobel, the aim of human rights litigation of bringing human rights violators to court seeks to provide justice to the individual victims. It can achieve redress where other remedies fail, provide recognition for "crimes which men can neither punish nor forgive" (Hannah Arendt, cited in Jeremy Sarkin, Germany's Genocide of the Herero, 1) serving as a tool of corrective justice, addressing a moral obligation and need. Such litigation can also serve the aim of retribution and deterrence through its high damages available, or it can serve the idea of reconciliation.

All these remedial ideas have to be seen, however, against more practical questions, such as to how much a financial settlement will actually recompense for human rights violations. What do the claimants want? Do they want a monetary sum, or official recognition and apportionment of blame for the wrongs that they suffered?

This short submission ends with the recognition of the important role which historical justice litigation can play in the context of human rights atrocities - past and present. US transnational litigation acknowledges the victim of human rights abuses as an individual claims holder and allows him a right to participate in the remedial process by recognising the independent right of ius standi of the victim. This right to remedial justice has been recognised in another jurisdiction, namely the United Kingdom, when the High Court allowed, at least in part, Kenyan victims of UK's counter insurgency measures during the Mau Mau emergency in Kenya during the 1950s, to sue the British government for alleged human rights violations (Ndiku Mutua and others $v$ The Foreign and Commonwealth Office [2011] EWHC 1913 (QB)).

\section{Tom Frost}

LL B (Hons) (Leic), PhD (Soton); Lecturer in Law, Newcastle Law School, Newcastle University.

Sascha-Dominik Bachmann

Reader in International Law, (University of Lincoln); State Exam in Law

(Ludwig-Maximilians Universität, Munich); Assessor Jur,

LL M (Stellenbosch), LL D. (Johannesburg).

Both authors are part of an international research project which investigates the potential of human rights litigation in the context of transitional justice; the project is in collaboration with colleagues from South Africa, Australia, Israel and the USA. Some findings of it were published as an article "Colonialism, Justice and the Rule of Law: a Southern African and Australian narrative" in 45 (2) De Jure. 